\title{
Antiplasmodial and larvicidal compounds of Toddalia asiatica root bark
}

\author{
T NYAHANGA $^{\mathrm{a}, *}$, J ISAAC JONDIKO ${ }^{\mathrm{a}}$, L ONYANGO AROT MANGURO ${ }^{\mathrm{a}, *}$ and \\ J ATIENO ORWA ${ }^{\text {b }}$ \\ ${ }^{a}$ Department of Chemistry, Maseno University, P. O. Box 333-40105, Maseno, Kenya \\ ${ }^{\mathrm{b}}$ Kenya Medical Research Institute, Centre for Traditional Medicine and Drug Research, \\ P. O. Box 54840-00200, Nairobi, Kenya \\ e-mail: nyahangat@yahoo.com; kamanguro@yahoo.com
}

MS received 30 July 2012; revised 19 March 2013; accepted 4 July 2013

\begin{abstract}
From the $n$-hexane, ethyl acetate and methanol extracts of Toddalia asiatica root bark were isolated eight compounds (1-8) which were identified on the basis of both spectroscopic and physical data as well as comparison with already published results. The crude extracts and isolated compounds showed moderate in vitro antiplasmodial activity against D6 (chloroquine-sensitive) and W2 (chloroquine-resistant) strains of Plasmodium falciparum. The extracts and isolates also exhibited larvicidal activities against Aedes aegypti and coumarins were identified as the active compounds.
\end{abstract}

Keywords. Toddalia asiatica; Rutaceae; coumarins; alkaloid; antiplasmodial; larvicidal activities.

\section{Introduction}

The plant Toddalia asiatica (L) Lam (Rutaceae) is a woody liana reaching a height of $10 \mathrm{~m}$ in forests as it uses other plants for support. ${ }^{1} 1 \mathrm{t}$ is widely used by various ethnic groups in Eastern Africa for treatment of myriad ailments including cough, bronchitis, cold, fever, influenza, malaria, bacterial infections, stomachache and snake bite. ${ }^{2}$ Recently, the plant leaves and root bark extracts were evaluated in vivo for antimalarial activity in mice against chloroquine-tolerant Plasmodium berghei NK 65 either alone or in combination with chloroquine. ${ }^{3,4}$ Significant parasitaemia suppressions of $31.7-59.3 \%$ was observed for root bark alone while the leaves and root bark in combination with chloroquine statistically improved suppressions within the range of $45.5-85.1 \%$. Previous phytochemical studies on the plant have led to the isolation and identification of coumarins, ${ }^{5-8}$ alkaloids ${ }^{9-12}$ and terpenoids. ${ }^{13}$ In this communication, we report the isolation of eight compounds from the plant root bark, of which compounds 4-6 have their ${ }^{13} \mathrm{C}$ NMR data being documented for the first time. The antiplasmodial and larvicidal activities of these secondary metabolites are also presented here.

*For correspondence

\section{Experimental}

\subsection{General experimental procedures}

Melting points were determined using Gallenkamp melting point apparatus and the values are uncorrected. Ultraviolet-Visible spectra were recorded on a PYE UNICAM SP 8-150 UV/VIS spectrophotometer. Mass spectral data were obtained on a MAT 8200 A Varian Bremen Instrument and acquired at $70 \mathrm{eV}$ ionization. Infrared data were recorded on Perkin-Elmer FTIR 600 series. NMR data were measured in $\mathrm{CDCl}_{3}$ and $\mathrm{CDCl}_{3}$-DMSO- $d_{6}$ (as dissolving solvents) on a Brucker NMR Ultrashield TM operating at 500 and $125 \mathrm{MHz}$, respectively.

\subsection{Plant material collection and preparation}

The roots of $T$. asiatica were collected from the wild at Kajulu location in the outskirts of Kisumu City, Kisumu County, Kenya in April 2010. Standard herbarium specimens were taken to the Department of Botany, University of Nairobi. Identification was done by Mr. Mathenge after comparison with authentic voucher specimens. The root barks removed from the roots were air dried under a shade and the dried plant materials were ground to fine powder. 


\subsection{Extraction of T. asiatica root bark}

One kilogram of the ground root bark was cold extracted sequentially using $n$-hexane, ethyl acetate and methanol (three litres each) with occasional shaking using an orbital shaker set at 150 revolutions per minute. The extracts were concentrated using a rotary evaporator in vacuo to yield yellow, orange and brown in colour materials with the yields of $18.0 \mathrm{~g}, 39.0 \mathrm{~g}$ and $100.0 \mathrm{~g}$, respectively.

\subsection{Isolation and characterization of compounds from $n$-hexane and ethyl acetate extracts}

Thin-layer chromatography (TLC) profiles of both the extracts revealed that compounds extracted by $n$-hexane were also present in the ethyl acetate. Therefore, $15 \mathrm{~g}$ of the former extract was combined with $30 \mathrm{~g}$ of the latter for column chromatography. Approximately $45 \mathrm{~g}$ of the combined extract was dissolved in a small amount dichloromethane $\left(\mathrm{CH}_{2} \mathrm{Cl}_{2}\right)$ and adsorbed onto silica gel for column chromatography $(5.0 \times 80 \mathrm{~cm}, 200 \mathrm{~g})$. Fractionation of the extract using gradient of $n$-hexane-ethyl acetate mixture, ethyl acetate and $\mathrm{MeOH}$ afforded 150 fractions (each $100 \mathrm{ml}$ ) whose compositions were monitored by TLC using solvent systems; $n$-hexane-ethyl acetate $(9: 1,4: 1,2: 1,1: 1)$ and $\mathrm{CH}_{2} \mathrm{Cl}_{2}$ - methanol (99:1 and 95:5), respectively. Those showing similar TLC profiles were combined resulting into four pools (IIV). Pool I (fractions 5-26, $7 \mathrm{~g}$ ) crystallized out and was separately filtered and recrystallized ( $n$-hexaneethyl acetate, 9:1) to give dihydronitidine $(1,290.5 \mathrm{mg})$. Fractions $27-40$ constituted pool II $(20 \mathrm{mg})$ which also crystallized out and after recrystallization ( $n$-hexaneEtOAc, 9:1) afforded aculeatin (2, $147.5 \mathrm{mg})$. The mother liquors from pools I and II upon further purification by repeated low pressure chromatography using $n$-hexane-EtOAc (9:1) followed by the same solvent system in the ratios $4: 1$ and $3: 2$, collecting $20 \mathrm{ml}$ each afforded a further $1(200.0 \mathrm{mg}), 2(87.5 \mathrm{mg})$, toddaculin $(\mathbf{3}, 194.5 \mathrm{mg})$ and suberosin $(\mathbf{4}, 45.0 \mathrm{mg})$, respectively.

Table 1. $\quad{ }^{1} \mathrm{H}$ NMR of compounds 1-7 from T. asiatica root bark.

\begin{tabular}{|c|c|c|c|c|c|c|c|}
\hline Carbon & 1 & 2 & 3 & 4 & 5 & 6 & 7 \\
\hline 1 & $7.66 \mathrm{~s}$ & & & & & & \\
\hline \multicolumn{8}{|c|}{10005} \\
\hline 3 & & $6.21 \mathrm{~d}(9.6)$ & $6.21 \mathrm{~d}(9.6)$ & $6.25 \mathrm{~d}(9.8)$ & $6.26 \mathrm{~d}(9.8)$ & $6.16 \mathrm{~d}(9.7)$ & $6.25 \mathrm{~d}(9.7)$ \\
\hline 4 & $7.50 \mathrm{~s}$ & $7.85 \mathrm{~d}(9.6)$ & $7.81 \mathrm{~d}(9.6)$ & $7.83 \mathrm{~d}(9.8)$ & $8.10 \mathrm{~d}(9.8)$ & $7.98 \mathrm{~d}(9.7)$ & $7.98 \mathrm{~d}(9.7)$ \\
\hline \multicolumn{8}{|l|}{$\begin{array}{l}4 \mathrm{a} \\
4 \mathrm{~b}\end{array}$} \\
\hline $\begin{array}{l}4 b \\
5\end{array}$ & & & & & & & \\
\hline $\begin{array}{l}5 \\
6\end{array}$ & $4.28 \mathrm{~s}$ & & & $7.20 \mathrm{~s}$ & & & \\
\hline \multicolumn{8}{|l|}{$6 a$} \\
\hline 7 & $7.10 \mathrm{~s}$ & & & & & & \\
\hline 8 & & $6.62 \mathrm{~s}$ & $6.60 \mathrm{~s}$ & $6.80 \mathrm{~s}$ & & $6.61 \mathrm{~s}$ & $6.83 \mathrm{~s}$ \\
\hline \multicolumn{8}{|l|}{$8 a$} \\
\hline \multicolumn{8}{|l|}{9} \\
\hline 10 & $7.47 \mathrm{~s}$ & & & & & & \\
\hline \multicolumn{8}{|l|}{$10 \mathrm{a}$} \\
\hline 11 & $7.69 \mathrm{~d}(8.5)$ & & & & & & \\
\hline 12 & $6.91 \mathrm{~d}(8.5)$ & & & & & & \\
\hline \multicolumn{8}{|l|}{$12 \mathrm{a}$} \\
\hline $1^{\prime}$ & & $2.87 \mathrm{~m}$ & $3.33 \mathrm{~d}(6.9)$ & $3.22 \mathrm{~d}(6.7)$ & & $6.74 \mathrm{~d}(8.4)$ & $2.78 \mathrm{~m}$ \\
\hline $2^{\prime}$ & & $2.87 \mathrm{~m}$ & $5.12 \mathrm{t}(6.9)$ & $5.25 \mathrm{t}(7.1)$ & $7.60 \mathrm{~d}(2.4)$ & $6.54 \mathrm{~d}(8.4)$ & $3.54 \mathrm{~m}$ \\
\hline $3^{\prime}$ & & & & & $6.98 \mathrm{~d}(2.4)$ & & \\
\hline $\mathrm{OCH}_{2} \mathrm{O}$ & $6.03 \mathrm{~s}$ & & & & & & \\
\hline Me-3' & & $1.39 \mathrm{~s}$ & $1.66 \mathrm{~s}$ & $1.65 \mathrm{~s}$ & & $1.28 \mathrm{~s}$ & $1.13 \mathrm{~s}$ \\
\hline $\mathrm{Me}-3^{\prime}$ & & $1.27 \mathrm{~s}$ & $1.76 \mathrm{~s}$ & $1.76 \mathrm{~s}$ & & $1.28 \mathrm{~s}$ & $1.13 \mathrm{~s}$ \\
\hline $\mathrm{OMe}$ & $3.91 \mathrm{~s}$ & 3.84 & $3.81 \mathrm{~s}$ & $3.90 \mathrm{~s}$ & $4.14 \mathrm{~s}$ & $3.95 \mathrm{~s}$ & $3.85 \mathrm{~s}$ \\
\hline $\mathrm{OMe}$ & $3.86 \mathrm{~s}$ & $3.89 \mathrm{~s}$ & $3.86 \mathrm{~s}$ & & $4.15 \mathrm{~s}$ & $3.95 \mathrm{~s}$ & $3.86 \mathrm{~s}$ \\
\hline $\mathrm{NCH}_{3}$ & $2.58 \mathrm{~s}$ & & & & & & \\
\hline $\mathrm{OH}-3^{\prime}$ & & & & & & 4.63 & \\
\hline $\mathrm{OH}$ & & & & & & & $4.10 \mathrm{~d}(5.4)$ \\
\hline $\mathrm{OH}$ & & & & & & & $4.10 \mathrm{~d}(5.4)$ \\
\hline
\end{tabular}

"s", "d", and "m" represents singlet, doublet and multiplet 
Pool III (fractions 45-75, $15 \mathrm{~g}$ ) upon repeated fractionation using $n$-hexane-ethyl acetate (4:1, 3:2 and 3:1) over silica gel column yielded a further $\mathbf{4}(15.0 \mathrm{mg}), \mathbf{2}$ $(80.0 \mathrm{mg})$ and isopimpinellin $(\mathbf{5}, 70.0 \mathrm{mg})$.

Pool IV (fractions 76-100, 22 g) yielded a gummy material after evaporation in vacuo and was further subjected to repeated low pressure chromatography using $n$-hexane-EtOAc (3:2 and 1:1) followed by $\mathrm{CH}_{2} \mathrm{Cl}_{2}$ $\mathrm{MeOH}(99: 1$ and 95:5) to give more of $5(45.0 \mathrm{mg})$ and toddalenol $(\mathbf{6}, 43.0 \mathrm{mg})$, respectively.

\subsection{Extraction and purification of $\mathrm{MeOH}$ extract}

The residue from EtOAc extraction was further extracted with $\mathrm{MeOH}(3 \mathrm{~L})$ in the cold for seven days, filtered and solvent removed using a rotary evaporator to give a brown material $(100 \mathrm{~g})$. A portion of the extract $(65.0 \mathrm{~g})$ pre-adsorbed on silica gel was fractionated through a silica gel column $(3 \times 60 \mathrm{~cm}, 250.0 \mathrm{~g})$ using $\mathrm{CH}_{2} \mathrm{Cl}_{2}-\mathrm{MeOH}$ gradient to pure $\mathrm{MeOH}$ affording 110 fractions of $50 \mathrm{ml}$ each. The composition of the fractions were monitored by TLC using solvent systems $\mathrm{CH}_{2} \mathrm{Cl}_{2}-\mathrm{MeOH}(4: 1,3: 2$ and 1:1) and those that exhibited similar TLC profiles were combined to constitute two major pools (V-VI). Fractions 14-80 (pool V, $12 \mathrm{~g}$ ) was further purified by flash chromatography using $\mathrm{CH}_{2} \mathrm{Cl}_{2}-\mathrm{MeOH}$ (97:3) followed by the same solvent system in the ratio 19:1 to afford more of $6(87.0 \mathrm{mg})$ and toddalolactone $(7,65.0 \mathrm{mg})$.

Similarly, fraction 81-110 (pool VI, 8.1 g) upon further purification using low pressure chromatography eluting with $\mathrm{CH}_{2} \mathrm{Cl}_{2}-\mathrm{MeOH}$ (17:3) followed by 4:1 gave non-UV active colourless powder which was identified spectroscopically as sucrose (8, $300.0 \mathrm{mg}$ ).

\subsection{Physical and spectral data of the compounds isolated from $T$. asiatica}

2.6a Dihydronitidine (1): Colourless crystals; Mp $172-173^{\circ} \mathrm{C}$ (from $10 \%$ EtOAc in $n$-hexane); UV $\left(\mathrm{CH}_{3} \mathrm{CN}\right) \lambda_{\max } \mathrm{nm}: 319.0,284.0,212.5$; IR $(\mathrm{KBr}) v_{\max }$ $\mathrm{cm}^{-1}: 2950,2888,1598,1494,1463,1415 ;{ }^{1} \mathrm{H}$ and ${ }^{13} \mathrm{C}$ NMR: see tables 1 and 2, respectively; ESI-MS: $\mathrm{m} / \mathrm{z}$ $350.3[\mathrm{M}+\mathrm{H}]^{+}$.

Table 2. ${ }^{13} \mathrm{C}$ NMR data of compounds 1-7 from $T$. asiatica root bark.

\begin{tabular}{|c|c|c|c|c|c|c|c|}
\hline Carbon & 1 & 2 & 3 & 4 & 5 & 6 & 7 \\
\hline 1 & 100.70 & & & & & & \\
\hline 2 & 148.00 & 160.98 & 161.27 & 160.80 & 160.47 & 159.99 & 160.14 \\
\hline 3 & 152.20 & 116.69 & 112.16 & 113.10 & 112.81 & 110.18 & 111.65 \\
\hline 4 & 104.30 & 138.82 & 138.97 & 142.63 & 139.40 & 138.81 & 139.54 \\
\hline $4 a$ & 130.80 & 107.11 & 107.03 & 109.22 & 107.59 & 102.76 & 106.50 \\
\hline $4 b$ & 126.30 & & & & & & \\
\hline 5 & & 155.95 & 155.11 & 127.60 & 144.27 & 155.22 & 155.89 \\
\hline 6 & 48.71 & 112.38 & 120.22 & 120.22 & 114.75 & 105.46 & 119.01 \\
\hline $6 a$ & 123.70 & & & & & & \\
\hline 7 & 118.60 & 161.68 & 161.62 & 160.38 & 149.99 & 160.93 & 161.83 \\
\hline 8 & 146.10 & 95.35 & 95.29 & 97.77 & 128.16 & 91.56 & 95.27 \\
\hline $8 \mathrm{a}$ & & 155.08 & 154.57 & 155.43 & 143.66 & 152.57 & 154.14 \\
\hline 9 & 147.40 & & & & & & \\
\hline 10 & 110.90 & & & & & & \\
\hline $10 \mathrm{a}$ & 126.20 & & & & & & \\
\hline $10 \mathrm{~b}$ & & & & & & & \\
\hline 11 & 120.10 & & & & & & \\
\hline 12 & 124.20 & & & & & & \\
\hline $12 \mathrm{a}$ & 142.70 & & & & & & \\
\hline $\mathrm{OCH}_{2} \mathrm{O}$ & 101.00 & & & & & & \\
\hline $1^{\prime}$ & & 23.45 & 22.63 & 23.50 & & 113.06 & 25.76 \\
\hline $2^{\prime}$ & & 63.08 & 122.07 & 121.80 & 145.10 & 142.45 & 75.67 \\
\hline $3^{\prime}$ & & 59.07 & 132.01 & 133.00 & 105.08 & 69.62 & 71.83 \\
\hline Me-3' & & 24.69 & 17.79 & 18.00 & & 30.23 & 25.39 \\
\hline Me- $3^{\prime}$ & & 18.85 & 25.67 & 25.00 & & 30.23 & 25.54 \\
\hline OMe & 55.80 & 63.54 & 56.00 & 56.00 & 60.80 & 56.20 & 62.94 \\
\hline OMe & 61.00 & 56.00 & 63.10 & & 61.70 & 56.20 & 56.24 \\
\hline $\mathrm{N}-\mathrm{CH}_{3}$ & 41.30 & & & & & & \\
\hline
\end{tabular}


2.6b Aculeatin (2): Colourless crystals; Mp 115$117^{\circ} \mathrm{C}$ (from $5 \%$ EtOAc in $n$-hexane); $[\alpha]_{\mathrm{D}}^{20}-13.6^{\circ}$ (c $0.5, \mathrm{MeOH}) ; \mathrm{UV}\left(\mathrm{CH}_{3} \mathrm{CN}\right) \lambda_{\max } \mathrm{nm}: 324.5$, 252.5, 243.0, 223.0 and 204.5; IR (KBr) $v_{\max } \mathrm{cm}^{-1}$ : 3200-3000, 2984, 2954, 2925, 2851, 1728, 1640; ${ }^{1} \mathrm{H}$ and ${ }^{13} \mathrm{C}$ NMR: see tables 1 and 2, respectively; ESI-MS (DCI-NH $\left.{ }_{3}\right): m / z 308.2\left[\mathrm{M}+\mathrm{NH}_{4}\right]^{+}$, $291[\mathrm{M}+\mathrm{H}]^{+}$

2.6c Toddaculin (3): Cream crystals; Mp 94-96 ${ }^{\circ} \mathrm{C}$ (from $40 \%$ EtOAc in $n$-hexane); $\mathrm{UV}\left(\mathrm{CH}_{3} \mathrm{CN}\right) \lambda_{\max }$ nm: 326.0, 253.0, 223.0, 204.5; IR (KBr) $v_{\max } \mathrm{cm}^{-1}$ : 3000-3200, 2920, 2856, 1733, 1650, 1550; ${ }^{1} \mathrm{H}$ and ${ }^{13} \mathrm{C}$ NMR: see tables 1 and 2, respectively; ESI-MS (DCI$\left.\mathrm{NH}_{3}\right): m / z \quad 566.4\left[2 \mathrm{M}+\mathrm{NH}_{4}\right]^{+}, 292.2\left[\mathrm{M}+\mathrm{NH}_{4}\right]^{+}$, $275.2[\mathrm{M}+\mathrm{H}]^{+}$.

2.6d Suberosin (4): Light yellow crystals; Mp 183 $185^{\circ} \mathrm{C}$ (from $10 \%$ EtOAC in $n$-hexane); $\mathrm{UV}\left(\mathrm{CH}_{3} \mathrm{CN}\right.$ ) $\lambda_{\max } \mathrm{nm}: 328.0,250.0$, 207.5; IR (KBr) $v_{\max } \mathrm{cm}^{-1}$ : 2960, 2845, 1726, 1660, 1570, 1475; ${ }^{1} \mathrm{H}$ and ${ }^{13} \mathrm{C}$ NMR: see tables 1 and 2, respectively; ESI-MS: $m / z 245.3$ $[\mathrm{M}+\mathrm{H}]^{+}$.

2.6e Isopimpinellin (5): Golden yellow crystals; Mp $147.5-148^{\circ} \mathrm{C}$ (from $30 \%$ EtOAc in $n$-hexane; UV $\left(\mathrm{CH}_{3} \mathrm{CN}\right) \lambda_{\max } \mathrm{nm}: 309.5,267.0,248.0,241.0,222.5$, 195; IR (KBr) $v_{\max } \mathrm{cm}^{-1}: 3420,3151,3082,3011$, 2949, 2841, 1719; ${ }^{1} \mathrm{H}$ and ${ }^{13} \mathrm{C}$ NMR: see tables 1 and 2, respectively; ESI- MS $\left(\right.$ DCI-NH $\left.{ }_{3}\right): m / z 510.3$ $\left[2 \mathrm{M}+\mathrm{NH}_{4}\right]^{+}, 246.12\left[\mathrm{M}+\mathrm{NH}_{4}\right]^{+}, 247[\mathrm{M}+\mathrm{H}]^{+}$.

2.6f Toddalenol (6): Greenish-yellow crystals; $\mathrm{Mp} 224-225^{\circ} \mathrm{C}$ (from $20 \%$ EtOAc in $n$-Hexane); $\mathrm{UV}\left(\mathrm{CH}_{3} \mathrm{CN}\right) \lambda_{\max } \mathrm{nm}: 317.0,288.5,259.0,216.5$; IR (KBr) $v_{\max } \mathrm{cm}^{-1}: 3450,3000-3200,2950,2840$, 1723, 1645, 1445; ${ }^{1} \mathrm{H}$ and ${ }^{13} \mathrm{C}$ NMR: see tables 1 and 2, respectively; ESI- MS (DCI-NH $\left.{ }_{3}\right) \mathrm{m} / z: 308.2$ $\left[\mathrm{M}+\mathrm{NH}_{4}\right]^{+}, 273.1[\mathrm{M}-\mathrm{OH}]^{+}$; EI-Ms $(70 \mathrm{eV}) \mathrm{m} / z: 290$ (3), $272(21)$

2.6g Toddalolactone (7): Colourless Crystals; Mp $141-141.5^{\circ} \mathrm{C}$ (from $1 \%$ methanol in DCM); UV $\left(\mathrm{CH}_{3} \mathrm{CN}\right) \lambda_{\max } \mathrm{nm}: 326.0,253.0,242.5,224.0,205.0$; IR (KBr) $v_{\max } \mathrm{cm}^{-1}: 3300,2930,2860,1732,1635 ;{ }^{1} \mathrm{H}$ and ${ }^{13} \mathrm{C}$ NMR: see tables 1 and 2, respectively; ESI- MS $\left(\mathrm{DCI}+\mathrm{NH}_{3}\right) \mathrm{m} / z: 634.5\left[2 \mathrm{M}+\mathrm{NH}_{4}\right]^{+}, 617.4[2 \mathrm{M}+\mathrm{H}]^{+}$, $326.3\left[\mathrm{M}+\mathrm{NH}_{4}\right]^{+}, 309.2[\mathrm{M}+\mathrm{H}]^{+}$; EIMS $(70 \mathrm{eV}) \mathrm{m} / z$ : $308[\mathrm{M}]^{+}$914, $290\left[\mathrm{M}-\mathrm{H}_{2} \mathrm{O}\right]^{+}(23), 272\left[\mathrm{M}-2 \mathrm{H}_{2} \mathrm{O}\right]^{+}$ (100).

\section{Bioassay}

\subsection{In vitro mosquito larvicidal assay}

The larvicidal activities of crude extracts and pure isolates of $T$. asiatica were evaluated against 2 nd instar larvae of Aedes aegypti according to WHO larval susceptibility test method. ${ }^{14}$ The larval bio-efficacy of test samples was determined by making serial dilutions of $100,50,25,12.5,6.253 .125 \mu \mathrm{g} / \mathrm{ml}$ and the bioassays were performed within a temperature range of $27^{\circ}-$ $30^{\circ} \mathrm{C}$ and relative humidity of $75.5 \pm 5 \%$ under light and dark cycles of $12 \mathrm{~h}$ each.

For control, $1 \mathrm{ml}$ of ethanol was added to $19 \mathrm{~mL}$ of water and for each concentration, the experiment was carried out in triplicates. A group of 20 larvae were counted and placed in each of the transparent plastic cups $(300 \mathrm{ml})$ that were used in carrying out the tests.

The number of the dead and moribund larvae were counted and recorded after $24 \mathrm{~h}$ and $48 \mathrm{~h}$. The larvae were considered dead or moribund if they were unresponsive to light within 3 min even after prodding with a needle. ${ }^{15}$ Mortality was corrected for the natural mortality observed in the negative controls using the formula $\mathrm{P}=(\mathrm{P} 1-\mathrm{C}) / 1-\mathrm{C},{ }^{15}$ where $\mathrm{P} 1$ denotes observed mortality and $\mathrm{C}$ represents the natural mortality observed from the negative control. The data obtained was subjected to log-probit regression analysis to calculate the median lethal concentrations $\left(\mathrm{LC}_{50}\right)$ values.

\subsection{In vitro antiplasmodial assay}

The samples (crude extracts and pure compounds) were assayed using an automated micro-dilution technique to determine the $\mathrm{IC}_{50}(50 \%$ growth inhibition of cultured parasites). ${ }^{16}$

The two strains of $P$. falciparum used were chloroquine resistant Indochina (W2) and chloroquine sensitive Sierra Leone D(6). Quinine, chloroquine and mefloquine were used as the reference drugs.

Test compounds $(5 \mathrm{mg})$ were dissolved in $5 \mathrm{ml}$ dimethyl sulphoxide (DMSO) to give stock solutions of $1 \mathrm{mg} / \mathrm{ml}$. To reach the desired starting concentration, the stock solutions were diluted in the media RPMI 1640 and $350 \mu \mathrm{L}$ of the test compounds or drug solutions loaded on to the wells of the first column of a sterilized 96 well flat bottom culture plates. This was followed by two-fold serial dilutions using a Biomek Automated Laboratory work station.

The last column of the plate was left for negative and positive control. The positive control consisted 
of three complete medium with serum (CMS) containing parasites whereas the negative control consisted of CMS and erythrocytes with no parasites. A $200 \mu \mathrm{L}$ of the parasitized blood (1\% parasitemia) and $6 \%$ haemacrit were added to each and incubated for $24 \mathrm{~h}$ at $37^{\circ} \mathrm{C}$ in $6 \% \mathrm{CO}_{2}$. These resulted in the first wells of each compound to be tested at a concentration of $50 \mu \mathrm{g} / \mathrm{ml}$. A $25 \mu \mathrm{L}$ of [3H] hypoxanthine was added per well and incubated for a further $18 \mathrm{~h}$ at $37^{\circ} \mathrm{C}$, then frozen at $-20^{\circ} \mathrm{C}$ for maximum lyses of erythrocytes. The content of the plates were harvested using an automated cell harvester from Puckered Bioscience and then left to dry. Scintillation fluid was added to the plates, sealed and then counted on a liquid scintillation counter and this gave raw data representing the parasites counts.

Computation of the concentration of drugs causing $50 \%$ inhibition of $(\mathrm{G}-3 \mathrm{H})$ hypoxanthine uptake $\left(\mathrm{IC}_{50}\right)$ was carried out by interpolation after logarithmic transformation uptake of both concentration and radioactivity in counts per minute (CPM) values using the formula indicated.

To calculate $\mathrm{IC}_{50}$, the mid point $\left(\mathrm{Y}_{50}\right)$ was calculated by the formula below.

$$
\begin{aligned}
\mathrm{Y}_{50}= & {[(\text { PRBC }- \text { CPM value })} \\
& -(\text { UNPRBC }- \text { CPM value })] / 2 \\
\mathrm{IC}_{50}= & \operatorname{antilog}\left[\log \mathrm{X}_{1}+\left(\log \mathrm{Y}_{50}-\log \mathrm{X}_{1}\right)\right. \\
& \left.\times\left(\log \mathrm{X}_{2}-\log \mathrm{X}_{1}\right)\right] / \log \mathrm{Y}_{2}-\log \mathrm{Y}_{1},
\end{aligned}
$$

where $\mathrm{IC}_{50}=50 \%$ growth inhibition of cultured parasites.

$X_{1}$ and $X_{2}=$ lower and higher concentration of the samples, respectively. $\mathrm{Y}_{1}=\mathrm{CPM}$ value which corresponds with $\mathrm{X}_{1} \cdot \mathrm{Y}_{2}=\mathrm{CPM}$ value which correspond with $\mathrm{X}_{2}$.

\section{Results and discussion}

\subsection{Phytochemical studies}

Chromatographic fractionation of $n$-hexane, ethyl acetate and $\mathrm{MeOH}$ extracts of T. asiatica root bark afforded eight compounds characterized as dihydronitidine (1), aculeatin (2), toddaculin (3), isopimpinellin (5), suberosin (4), toddalenol (6), toddalolactone (7) and $\alpha$-D-sucrose (8). The isolates were identified using spectroscopic methods (UV, IR, ${ }^{1} \mathrm{H}$ and ${ }^{13} \mathrm{C} \mathrm{NMR}$, and
MS) as well as comparison with already documented literature. ${ }^{6,12,17-21}$
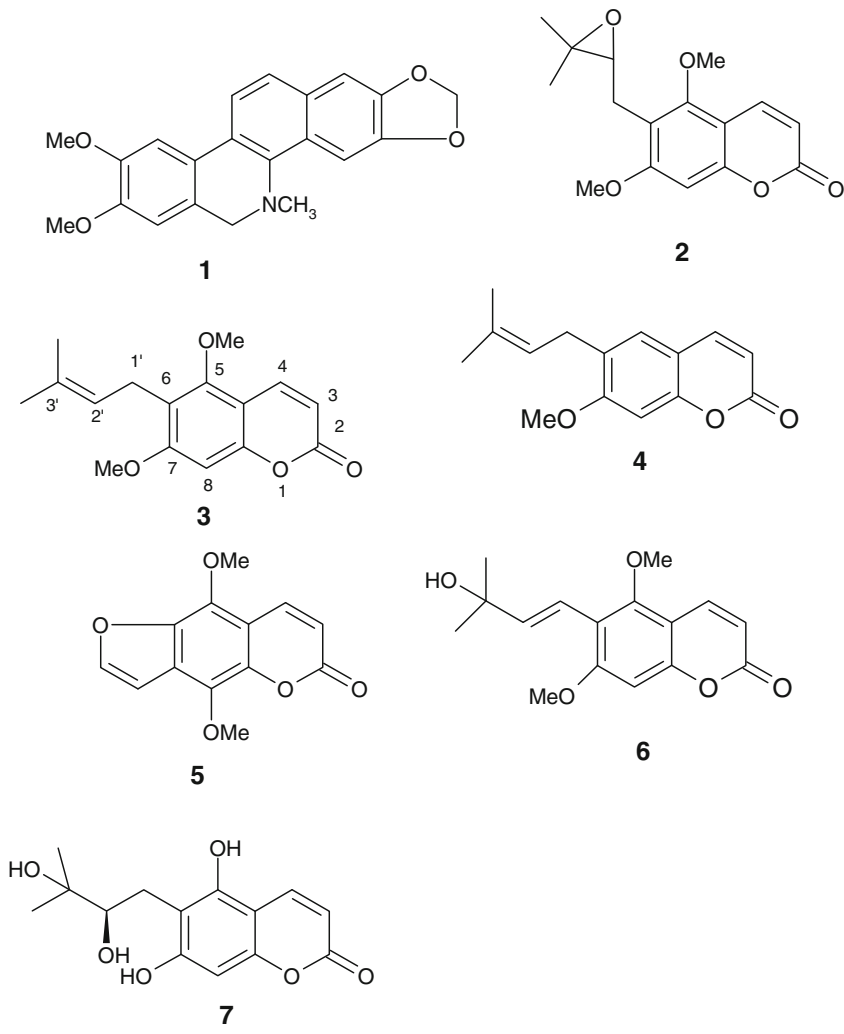

\subsection{Larvicidal activity of crude extracts and pure isolates from T. asiatica against Aedes egypti}

$n$-Hexane, ethyl acetate and methanol extracts and isolated compounds from the root bark were tested for their potency against mosquito larvae and the result are as shown in table 3 . The $n$-hexane extract showed the best activity with $\mathrm{LC}_{50}$ value of $9.4 \pm 1.0 \mu \mathrm{g} / \mathrm{ml}$ after $48 \mathrm{~h}$ exposure as compared to ethyl acetate $13.8 \pm$ $3.5 \mu \mathrm{g} / \mathrm{ml}$ and methanol $50.1 \pm 3.0 \mu \mathrm{g} / \mathrm{ml}$ after the same exposure duration.

The isolate toddalenol (6) was the most toxic with $\mathrm{LC}_{50}$ value of $6.4 \pm 1.0 \mu \mathrm{g} / \mathrm{ml}$ after $48 \mathrm{~h}$ exposure to the test organisms. The $\mathrm{LC}_{50}$ values for others were as follows: isopimpinelin (5) $7.6 \pm 1.0 \mu \mathrm{g} / \mathrm{ml}$, toddaculin (3) $10.2 \pm 2.0 \mu \mathrm{g} / \mathrm{ml}$, dihydronitidine (1) $11.8 \pm$ $2.5 \mu \mathrm{g} / \mathrm{ml}$, toddalolactone (7) $497 \pm 4.5 \mu \mathrm{g} / \mathrm{ml}$ after same exposure duration. Aculeatin (2) did not show any activity even at a high concentration of $100 \mu \mathrm{g} / \mathrm{ml}$. The larvicidal potency of T. asiatica and its constituents against Aedes aegypti is reported for the first time. All the coumarins isolated had same skeleton but with varied biopotency. The differences in toxicity could be due to varied substituents on the parent molecules. From the test results, it can be noted that at $48 \mathrm{~h}$ test 
Table 3. $\mathrm{LC}_{50}$ of $T$. asiatica extracts and constituents against 2 nd instar larvae of Aedes Aegypti after $24 \mathrm{~h}$ and $48 \mathrm{~h}$ exposure, respectively.

\begin{tabular}{lcc}
\hline \multicolumn{1}{l}{ Sample } & $\mathrm{LC}_{50}(\mu \mathrm{g} / \mathrm{ml})$ in $24 \mathrm{~h}$ & $\mathrm{LC}_{50}(\mu \mathrm{g} / \mathrm{ml})$ in $48 \mathrm{~h}$ \\
\hline Crude extracts/isolated compounds & & \\
$n$-Hexane & $10.4 \pm 2.0$ & $9.4 \pm 1.0$ \\
Ethyl acetate & $13.8 \pm 3.5$ & $13.8 \pm 3.5$ \\
Methanol & $57.2 \pm 5.0$ & $50.1 \pm 3.0$ \\
Dihydronitidine (1) & $12.2 \pm 3.5$ & $11.8 \pm 2.5$ \\
Aculeatin (2) & $\mathrm{NA}$ & $\mathrm{NA}$ \\
Toddaculin (3) & $509 \pm 2.5$ & $10.2 \pm 2.0$ \\
Isopimpinelin (5) & $8.2 \pm 0.5$ & $7.6 \pm 1.0$ \\
Todalenol (6) & $6.8 \pm 0.5$ & $6.4 \pm 1.0$ \\
Toddalolactone (7) & $509 \pm 5.5$ & $497 \pm 4.5$ \\
\hline
\end{tabular}

Key: NA $=$ not active

duration, extracts and isolates showed better $\mathrm{LC}_{50}$ values than at $24 \mathrm{~h}$ exposure. This suggested that at longer test duration the samples could be more toxic to the larvae.

\subsection{Antiplasmodial activity of T. asiatica crude extracts and isolated compounds}

Chloroquine-resistant Indochina (W2) and chloroquinesensitive Sierra-Leone (D6) strains of Plasmodium falciparum were used in this test. Crude extracts from the root bark were potent against the resistant strain of the parasite with the highest activity recorded with ethyl acetate extract; $\mathrm{IC}_{50} 9.4 \pm 1.1 \mu \mathrm{g} / \mathrm{ml} . n$-Hexane and methanol extracts had values of $\mathrm{IC}_{50} 26.4 \pm 0.1$ and $15.6 \pm 2.5 \mu \mathrm{g} / \mathrm{ml}$, respectively.
Among the isolates, the alkaloid dihydronitidine (1) was fairly active against both strains of parasite with $\mathrm{IC}_{50}$ values of $6.5 \pm 1$ and $8.7 \pm 1.1 \mu \mathrm{g} / \mathrm{ml}$ against $\mathrm{W} 2$ and D6 strains, respectively. This activity is quite low compared to nitidine ${ }^{8}$ which had $\mathrm{IC}_{50}$ values of $9 \mathrm{ng} / \mathrm{ml}$ and $108 \mathrm{ng} / \mathrm{ml}$ against $\mathrm{W} 2$ and D6, respectively. Thus, reduction of nitidine to dihydronitidine reduces its ability to bind to the DNA protein of the parasite. ${ }^{22}$ Coumarins showed comparable activity to the alkaloid with isopimpinellin (5) being most active against W2 with $\mathrm{IC}_{50}$ value of $6.0 \pm 2.0 \mu \mathrm{g} / \mathrm{ml}$ while toddaculin (3) was the most active against $\mathrm{D} 6$ strain with $\mathrm{IC}_{50}$ value of $4.5 \pm 0.1 \mu \mathrm{g} / \mathrm{ml}$ (table 4). The biopotency of toddaculin (3), isopimpinellin (5) and aculeatin (2), were much better than coumarins previously reported. ${ }^{7}$ The antiplasmodial activities of dihydronitidine (1), aculeatin (2),

Table 4. In vitro $\mathrm{IC}_{50}$ values of crude extracts and constituents of $T$. asiatica against W2 and D6 strains of Plasmodium falciparum.

\begin{tabular}{lcc}
\hline Sample/drug & $\mathrm{W} 2(\mu \mathrm{g} / \mathrm{ml})$ & $\mathrm{D} 6(\mu \mathrm{g} / \mathrm{ml})$ \\
\hline Extracts & & \\
$\quad$-Hexane & $26.4 \pm 0.1$ & $26.1 \pm 0.3$ \\
Ethyl acetate & $9.4 \pm 1.1$ & $12.4 \pm 0.9$ \\
$\quad$ Methanol & $15.6 \pm 2.5$ & $17.1 \pm 1.6$ \\
Isolated compounds & & \\
$\quad$ Dihydronitidine $(\mathbf{1})$ & $6.5 \pm 1.6$ & $8.7 \pm 1.1$ \\
Aculeatin $(\mathbf{2})$ & $8.3 \pm 1.1$ & $7.6 \pm 1.7$ \\
Toddaculin $(\mathbf{3})$ & $6.1 \pm 1.3$ & $4.5 \pm 0.1$ \\
Isopimpinelin $(\mathbf{5})$ & $6.0 \pm 2.0$ & $7.0 \pm 1.6$ \\
Todalenol $(\mathbf{6})$ & $\mathrm{NA}$ & $\mathrm{NA}$ \\
Toddalolactone $(\mathbf{7})$ & $14.1 \pm 0.1$ & $15.6 \pm 0.6$ \\
Standard drugs & & \\
Chloroquine & $0.576 \pm 0.005$ & $0.0032 \pm 0.045$ \\
Mefloquine & $0.009 \pm 0.001$ & $0.023 \pm 0.001$ \\
Quinine & $0.098 \pm 0.020$ & $0.0208 \pm 0.015$ \\
\hline
\end{tabular}

Key: NA $=$ not active 
toddalolactone (7), isopimpinellin (5) and toddaculin (3) are being reported for the first time. The activity of the coumarins could be due to $\alpha, \beta$-unsaturated keto group. ${ }^{23}$ Activity observed could be attributed to the reason why the plant is used to treat malaria and its associated symptoms by traditional health practitioners.

\section{Conclusion}

The present study describes the compounds isolated from T. asiatica and their biological activities. The findings validate the use of the plant in herbal medicine against malaria. The compound structures were confirmed by IR, NMR and mass spectral data.

\section{Acknowledgements}

We acknowledge support from the Inter University Council for Eastern Africa (IUCEA) through VicRes for funding the project. Mr. S G Mathenge is thanked for the identification of the plant material. Prof. Lutz Tietze of Georg-August University Goettingen is also thanked for providing both NMR and MS analysis.

\section{References}

1. Usher G 1974 A dictionary of plant used by man (London: Constable LTD) p. 113

2. Kokwaro J O 1976 Medicinal plants of East Africa (Nairobi: Kenya Literature Bureau) p. 123

3. Muregi F W, Ishih A, Miyose T, Suzuki T, Kino H, Amano T, Mkoji G M and Terada M 2007 J. Ethnopharmacol. 111190

4. Muregi F W, Ishih A, Miyose T, Suzuki T, Kino H, Amano T, Mkoji G M and Terada M 2007 Phytother. Res. 21337

5. Buckingham J 1994 Dictionary of natural products (London: Chapman and Hall) Vol. 7, p. 78
6. Chen Y C, Tsai W J, Wu M H, Lin L C and Kuo Y C 2007 Br. J. Pharmacol. 150298

7. Oketch-Rabah H A, Mwangi J W, Listergen J and Mberu F K 2000 Fitoterapia 71636

8. Heather E K, Suryanarayana V V, Matthew F S, Melissa J R and John D 2002 J. Carcinog. 231667

9. Gakunju D M N, Mberu E K, Dossaji S F, Gray A I, Waigh R D, Waterman P G and Watkins W M 1995 Antimicrob. Agents Chemother. 392606

10. Lakshmi V, Kapoor S, Pandey K and Patnaik G K 2002 Phytother. Res. 16281

11. Rashid M A, Gustafson K R, Kashman Y, Cardellina J H, McMahon J B and Boyd M R 1995 Nat. Prod. Lett. 6 153

12. Ishii $\mathrm{H}$, Kobayashi $\mathrm{J}$, Ishikawa $\mathrm{T}$, Haginiwa $\mathrm{J}$ and Ishikawa T 1991 Yakugaku Zasshi 111365

13. Ping H, Karagianis G, Wei-Shan X and Waterman P 2005 Nat. Prod. Res. Dev. 1782

14. WHO 1981 Instructions for determining the susceptibility or resistance of mosquito larvae to insecticides, WHO/VBC/81 pp. 807

15. WHO 2005 Guidelines for laboratory and field testing of mosquito larvicides, WHO/CDS/WHOPES/ GCDPP/2005

16. Trager W and Jensen J B 1976 Science 673

17. Iwasaki H, Oku H, Takara R, Miyahira H, Hanashiro K, Yoshida Y, Kamada Y, Toyokawa T, Takara K and Inakuju M 2006 Cancer Chemother. Pharmacol. 81

18. Ishii H, Kobayashi J, Sakurada E and Ishikawa T 1992 J. Chem. Soc. 11681

19. Gopalakrishna E M, Bittner M, Silva W H and Watson W H 1977 J. Cryst. Mol. Struct. 7107

20. Furukawa H, Ito C and Mizuno T 1990 J. Chem. Soc. 1 1593

21. Tsai Wu M F, Teng C M, Ishikawa T and Chen S 1998 Phytochemistry 481377

22. Ochieng C 2008 Evaluation of bioactive constituents of Gardenia Ternifolia and metabolites of the bark of Millettia for malaria control principles. MSc Thesis, Maseno University p. 250

23. Bray D H, Warhurst D C, Connoll J D, O'Neill M J and Phillipson J D 1990 Phytother. Res. 429 